\title{
IMPORTANCE OF ANIMATION ACTIONS IN THE OPERATION OF HUNGARIAN LOCAL ACTION GROUPS
}

\author{
Judit Katona-Kovács ${ }^{1}$, Chris High², Gusztáv Nemes ${ }^{3}$
}

Received 31 May 2011; Accepted 16 December 2011

\begin{abstract}
The EU LEADER initiative has been running for 20 years and plays an important role in the development of European rural areas, however, in countries joining to the EU after 2004 it is still a relatively new phenomenon. In Hungary, for example, the LEADER+ programme was launched in 2005 with an experimental phase (called a "LEADER type initiative") and has developed to be a fully applied EU programme only in the current programming period. This paper explores the implementation of the LEADER programme in eastern Hungary. The examined Local Action Groups face diverse challenges concerning human, social, physical and financial capital, networks and social learning. The study investigates the opportunities and threats faced by the LAGs, with special regard to institutions, governance and applied initiatives. The roles of the LAGs within the social, economic and cultural context of given areas are examined through Lukesch's (2007) model FOG - forms of governance. The model is a tool to explore the interrelationships local partnership, local needs and local socio-cultural environment. The results of the FOG test show that the prevailing mode of governance in the examined LAGs emphasises animation actions as important elements of operation. Although the importance of animation actions is underlined by the result of the test, their presence between the initiatives is less than it should be. Good examples of animation actions are given: participatory video and a case study of its Hungarian application are introduced. Finally the role of Universities in animation actions is emphasised and closer relation of them with RD networks is called for.
\end{abstract}

Keywords: LEADER, Hungary, rural development, social learning, animation actions, policy analysis

Absztrakt:A LEADER program az EU vidékfejlesztési politikái között immár 20 éve kitüntetett szerepet játszik, a 2004 után csatlakozó tagországok körében azonban még ma is újdonságnak számít. Magyarország kísérletképpen már 2002-ben próbálkozott a programmal és az EU csatlakozás után rögtön elindította a LEADER+ programot. Mégis, a jelenlegi 2007-13-as az első programozási ciklus, melyben a LEADER a hazai szakpolitika teljes jogú tagjaként szerepel. Cikkünk a LEADER program kelet magyarországi megvalósítását vizsgálja. A megkérdezett Helyi Akciócsoportokat

\footnotetext{
1 Judit Katona-Kovács, University of Debrecen, Hungary, katonaj@agr.unideb.hu

${ }^{2}$ Chris High, Open University, United Kingdom, c.high@open.ac.uk

${ }^{3}$ Gusztáv Nemes, MTA KTI \& Corvinus University, Budapest, nemes@econ.core.hu
} 
(HACS) különféle kihívások elé állítja az emberi, társadalmi, a technológiai és pénzügyi erőforrások fejlesztése és kiaknázása, a helyi hálózatok építése és a társadalmi tanulás folyamatainak segítése. A tanulmány a lehetőségeket és a veszélyeket elsősorban az intézmények, a helyi kormányzás és a program során alkalmazott intézkedések vizsgálatára alapozva igyekszik feltárni. A HACS-ok adott társadalmi, gazdasági, kulturális térben játszott szerepét a Lukesch (2007) által felállított modell alkalmazásával vizsgáljuk meg, elemezzük a helyi partnerség, a helyi szükségletek és a társadalmi-kulturális környezet között felfedezhetö összefüggéseket. Az elemzés szerint a helyi kormányzás jelenleg elért szintjén a társadalmi animáció eszközeinek fontos szerepet kellene kapniuk a program működtetésében. Bár a társadalmi animáció elvileg kiemelt helyen szerepel a program eszközrendszerében, a gyakorlati megvalósítás során már nem elég hangsúlyos. A tanulmány a közösségi videó hazai alkalmazását, mint a társadalmi animáció sikeres eszközét mutatja be, végül kiemeli az egyetemek lehetséges/kívánatos szerepét a társadalmi animáció eszközeinek kidolgozásában és alkalmazásában és felhívja a figyelmet a vidékfejlesztési hálózatokkal történő szorosabb együttmüködés szükségességére.

Kulcsszavak: LEADER, Magyarország, vidékfejlesztés, társadalmi tanulás, animációs eszközök, politikai elemzés

\section{Introduction}

\section{Rural change - evolution or planned transition?}

Most rural change is evolutionary rather than planned transition (sensu Loobarch and Rotsmans, 2006). Changes in rural areas are often indirect, the result of goals linked to other sectors or territories, such as urban areas. Odor et al. (2009), in their examination of national sustainable development strategies and national rural development programmes, conclude that there are no commonly accepted objectives or principles about the desired extent of demographic changes in rural areas. Aims vary, including "reducing, stopping, stabilising and reversing" the depopulation of rural areas (ibid). As well as demographic change, economic structural change and globalisation also result in the social and economic decline of certain rural areas in almost all EU member states. Weber (2010) calls attention to the need for spatial planning to work on processes of growth and decline in parallel. She finds it important to strategically control and also design the socio-economic change in declining regions through spatial planning.

The question therefore arises: can we actually plan/help/accelerate rural change through development policies and redistribution of public money? Although Loobarch and Rotsman and others say that rural change is evolutionary, we would argue along with Weber (ibid.) that there is scope for agency - for learning lessons from other times and places will help us make rural change work better here and now.

\section{Institutions matter}

The question of institutions is an important theme in the literature, which has to be kept in mind when examining agency in rural areas. We took two approaches to examine the complexity of institutions, the framework from Woodhill and the four levels of institutions (Williamson, 2000 in: Salverda 2009). Woodhill (2008:6) draws up a framework for exploring the complexity of institutions. He calls attention to thinking critically about institutions as a key to social changefocused development and considering the messy web of many interacting institutions concerned. When thinking about bottom up development and the institutions of the LEADER Programme for example, as a "control" (following Woodhill's categorisation (2008:6)), the success or failure of the programme largely depends on the individual institutions and their success in communicating and co-operating with each other in the framework of the programme. 
The discussion along a workshop linked to the Rural Jobs FP7 research (Katona-Kovács, 2010) also underlined the complexity of the problem:

"EU policy jargon, technical vocabulary is not understood by the rural population, they do not know what is behind, only know that there are some funds available" Romania

"..there is a danger of subventing the formal democratic process: some local groups elected formal representatives" UK

"the main problem is the coordination between bodies and stakeholders" Spain

"bottom up approach is important for local planning, but has to be combined with top down, people of local level are not good enough in strategic management" Lithuania

Kovács (2004) in his work, at the same time refers to a Hungarian proverb saying that political change takes months, economic change takes years, while social change needs 50 years to take place. We can find similar message in an OECD rural policy review, "a new policy area is said to take 30 years to develop" (OECD, 2007:115).

Considering the timescale needed for development, it is probably "meaning" (social change) that of the elements of Woodhill's frame that requires the longest time for change. This is supported by the New Institutional Economics (NIE) literature, where social embeddedness (Salverda, 2009) is the field where - within the four institutional levels concerned - the longest time (some 50 to 100 years) is needed, for real structural changes.

In our review of institutions we found that the frame drawn by Woodhill and the four level of institutions of NIE are overlapping (Table 1). These resources mentioned above (such as trust and human relations) belong to social embeddedness or in the frame of meaning. This part of the institutions models need the longest time for change.

\begin{tabular}{|l|r|c|}
\hline Four levels of institutions & Framework of institutions & Period of change years \\
\hline Social embeddedness & $\begin{array}{c}\text { Meaning } \\
\text { (Beliefs and understanding) }\end{array}$ & 10 to 100 \\
\hline Institutional environment & $\begin{array}{c}\text { Control } \\
\text { (Mandates, policies and strategies) }\end{array}$ & 1 to 10 \\
\hline Institutions of governance & $\begin{array}{c}\text { Association } \\
\text { (Organizations and networks) }\end{array}$ & Continuous \\
\hline Incentives and motives & $\begin{array}{c}\text { Action } \\
\text { (Regular practices and behaviours) }\end{array}$ & 10 . \\
\hline
\end{tabular}

Tab 1. Overlap of institution models. Source: Williamson, 2000 in: Salverda, 2009; Woodhill, 2008

\section{Towards agency, animation and a "real life laboratory"}

In the literature, the concept of rural development has evolved over time (Terluin and Post, 1999). More recently, concepts of neo-endogenous and integrated rural development have gained ground, in which the control of the process is recognised as an interplay between local and external forces. Ploeg et al. (2008) suggest that endogeneity refers to the degree in which a regional economy is grounded on regionally specific resources and, simultaneously develops them. They hypothesise that the more endogeneity in a regional economy, the higher the competitive advantage of the region concerned will be.

Kovách and Kristóf (2009:58) in their work state, that "A comparative perspective on new rural development needs to recognise the significance of the roles of intermediate actors, within the activities undertaken, including the motivation of local actors and the commercialisation of rural goods and services (RGS). This refers to the capacity of intermediate actors to adapt any policy or regulation. Depending on their social, political and economical interests, on the one 
hand, or local circumstances, on the other, they are capable of exercising impact on the flow of goods, capital and knowledge." (Kovách and Kristóf, 2009:58) They also suggest that according their role as intermediate actors, three different models may be relevant: the French "multiple", the Finnish and Dutch "organised" and the Spanish and Hungarian "adaptive" models." They found the Hungarian "adaptive model less regulated compared with the other two. "In Hungary, after joining the EU, a mixture of regulations is still in force and intermediate actors, principally, adopted individual strategies. The intermediate actors adapt to these rapidly changing conditions, combining elements of personal and cooperative actions, but their activity to provide $R G S$ remains rather individual.

- A less organised system with embryonic, but increasing cooperation and harmonisation, with the dominance of non-coordinated individual actions.

- Decisive role of intermediate actors in providing RGS with a strong individual character.

- "Quasi chaos" conditions: rapidly changing, unclear regulation, dominance of political and economic stakeholders.

- Benefits to intermediate actors from transmittance RGS are market profit, which legitimises transforming the social, political structure and hierarchy." (Kovách and Kristóf, 2009:54)

To try out some of the emerging ideas in practice and to provide a "real life laboratory" for innovation in rural development the LEADER Programme was introduced in the EU in the early 1990's. Bottom-up rural development policies brought localities, local communities and organisations into focus. Their participation, roles and functions were reassessed and re-valued in the development process. The LEADER Programme provided support for local communities to establish partnerships and development agencies, work out their own strategic development plans and to implement them through channelling EU funding to local economic and social actors.

In Hungary this shift could effectively begin only around the turn of the Millennium, when trying to fulfil requirements for EU accession the central bureaucratic system started to recognise heuristic local development system (Nemes et al., 2006), along with the growing importance of rural NGOs. (Varga, 2009). The EU LEADER initiative therefore has almost 20 years history and plays an important role in the development of European rural areas, however, in EU-10 countries it is still a relatively new phenomenon. In Hungary, for example, the programme was launched in 2005 with an experimental phase (called a "LEADER type initiative") and has developed to be a fully applied EU programme only in the current programming period.

LEADER today plays an important and indispensable role in Hungarian rural development in supporting a strategic and active approach to rural change, even if it cannot stop socioeconomic decline in every case. Keeping in mind the historical background, the time period for change of the institutions in the EU-12 and the ageing population, this study intends to answer several questions:

- what type of governance, or/and what level of institutional development is prevailing in Hungarian LEADER LAGs?

- what types of projects and initiatives are supported, and whether these are in line with the state of their institutional development (type of governance) of the LAG?

- how should/could resources be allocated to make rural development work better in Hungary?

To answer the first two questions we use the available literature, an empirical, questionnaire based study, examining the level of institutional development and the type of actions undertaken by selected Hungarian LAGs. While to have an answer to the third question, we also explore the possibilities and development value of actions in the field of social animation through two short case studies, one involving participatory video and the other the co-operation between university departments and poor rural areas in marginal regions of Hungary. 


\section{Methodology}

During the research we examined four LAGs operating in the North-east of the Great Hungarian Plain. Our main concerns were the particular model of governance they applied and their actions in the field for social animation. The methodology was based on the analytical approach and guidelines and on the structured questionnaires set out by the LAG Handbook (Lukesh, 2007). With various representatives of the four examined LAGs altogether 15 questionnaires were conducted in person by the research team ${ }^{4}$. Interviewers experienced great difficulties in getting answers even when there were existing relationship with the interviewees, as a result of time pressure, work load of rural development managers. For validity, Lukesh suggests to conduct the questionnaire with several representatives of a LAG in parallel, in order to get a more reliable image of the prevailing mode of governance in the area. In our case the 15 questioners conducted varied between the 4 examined LAGs, 1, 2, 5 and 7 respectively.

The type of governance was examined through the FOG test (forms of governance, Lukesch, 2007:19) following the list of 64 questions (8x8) to identify the predominant mode of governance in a rural area. Each level of governance from 1 to 8 (from 1=existence to 8=sustainability, Figure 1) was represented by one key question. For each key question eight possible answers were offered representing one of the eight levels. Respondents were asked to tick a maximum of three answers in the randomised questioner so as not to identify the pattern of the questions. On the bases of the selected answers the average value of governance (so as the type of governance) was calculated. In order to avoid the situation that respondents would tick the boxes according to their wishes and not to their perception of the real conditions, they were asked to do the test twice, once with regard to the perceived reality, and once with regard to their own view of how things should be.

To examine which kind of operations are presented in given LAGs from the three modes of operation offered by the model - animation actions, structuring actions, consolidating actions (Figure 1) - Lukesch suggests two methods. One includes collecting the concrete activities (projects) and classifying them. The other is by examining at the LAG's working style and preferred type of projects to be supported through a questionnaire. In the study we applied the second method and used the frame by Lukesch (2007:22) that provided cues to assess the predominant pattern. In this case as well (as it was suggested) we randomised the sequence of answers.

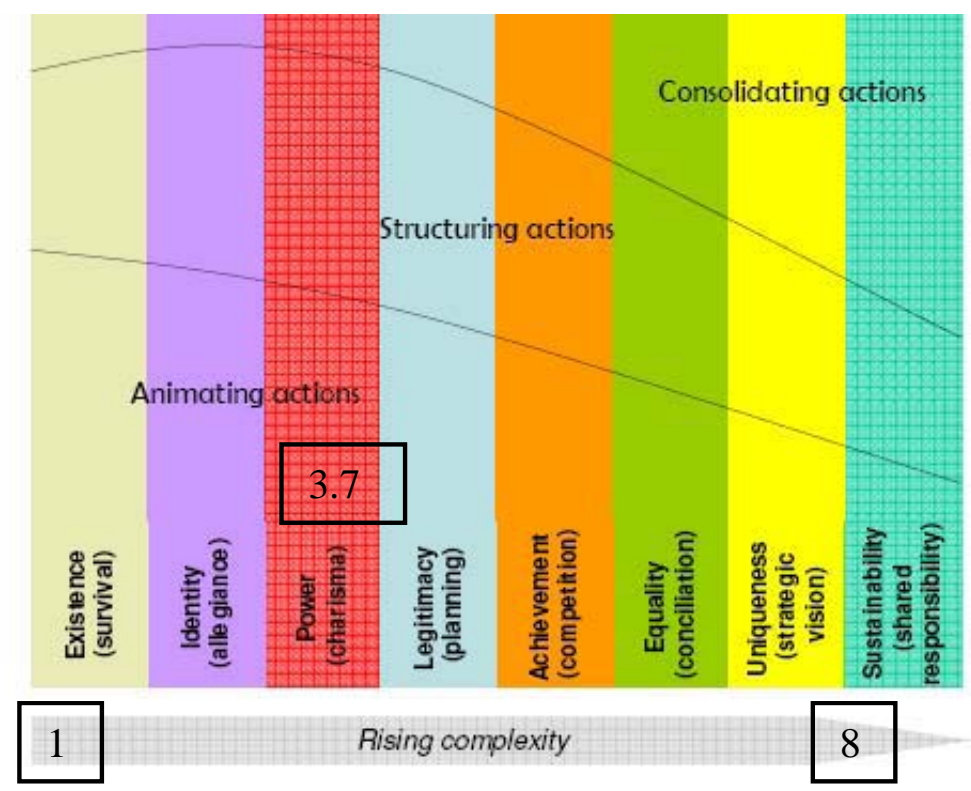

Fig 1. Eight modes/levels of governance and three modes of operations. Source: Lukesch (2007:23).

\footnotetext{
${ }^{4}$ Here we would like to acknowledge the work of three students who helped conducting 10 interviews altogether: Veronika Tótok, Gergő Szabó and Péter Zsidai. Different phases of our work were supported by the János Bolyai Research Fellowship of the Hungarian Academy of Sciences, the Norvegian Financial Mechanism, the Marie Curie Reintegration Fellowship and the Institute of Economics of the Hungarian Academy of Sciences.
} 


\section{Results of the research}

\section{Governance}

According to our questionnaires, concerning governance the examined LAGs mainly positioned themselves with the level 3.7 at the closest to Power (Charisma) (where bottom up feature of LEADER is addressed) and Planning type (where partnership is addressed) (see Table 2 and Figure 1) of the FOG test.

Answers regarding desired governance in the future express a wish that it should be done on the $6^{\text {th }}$ level, in Conciliation type (bottom up and partnership approach addressed together).

\begin{tabular}{|l|r|r|}
\hline & \multicolumn{1}{|c|}{ Present } & \multicolumn{1}{c|}{ Future } \\
\hline LAG1 & 3.6 & 6.5 \\
\hline LAG2 & 4.0 & 5.4 \\
\hline LAG3 & 3.3 & 6.2 \\
\hline LAG4 & 3.9 & 5.8 \\
\hline \hline Average & $\mathbf{3 . 7}$ & $\mathbf{6 . 0}$ \\
\hline
\end{tabular}

Tab 2. Results of the FOG test. Source: own calculation.

The local partnership articulates the needs of local people and amplifies the local processes of self-awareness and expressions of will. With further analysis, question by question (see Annex 1 and Table 3 ) in the case of the first 5 questions the results show a lower level of governance within the model. Answers are mainly linked to the first three levels of governance. People in the examined regions fight for survival and there is a high level of unemployment. As one of the residents said, "today we do not find engineers and farmers in the village, the only intellectuals are teachers and officials". Speaking with younger people reveals that they plan to leave the village.

\begin{tabular}{|c|c|c|}
\hline $\begin{array}{l}\text { 1. What is the } \\
\text { essential theme } \\
\text { for people in this } \\
\text { area? }\end{array}$ & 1. To fight for survival & 11 \\
\hline \multirow{3}{*}{$\begin{array}{l}\text { 2. What is local } \\
\text { identity and } \\
\text { belonging } \\
\text { grounded upon? }\end{array}$} & 1. Everybody is on his/her own, there is no local identity & 4 \\
\hline & 2. Through traditional (familiar, religious, ethnic, professional or political) ties & 11 \\
\hline & 3. Charismatic LEADERs gather followers around them & 9 \\
\hline \multirow{3}{*}{$\begin{array}{l}\text { 3. How does } \\
\text { power articulate } \\
\text { itself in the area? }\end{array}$} & 1. Everybody has to care for him/herself & 0 \\
\hline & 2. People's aspirations are advocated by those who traditionally assume this role & 8 \\
\hline & 3. People entrust themselves to convincing and strong personalities & 11 \\
\hline \multirow{3}{*}{$\begin{array}{l}\text { 4. How is local } \\
\text { development } \\
\text { organised? }\end{array}$} & 1. Local development is not steered, it keeps “drifting” & 4 \\
\hline & 2. By carrying out their habitual duties people serve the whole as well & 1 \\
\hline & 3. Key stakeholders tell what has to be done & 12 \\
\hline \multirow{3}{*}{$\begin{array}{l}\text { 5. How is } \\
\text { territorial } \\
\text { competitiveness } \\
\text { enhanced? }\end{array}$} & 1. The essential impulsions come from outside & 3 \\
\hline & 2. Through relying on traditional values and abilities & 12 \\
\hline & 3. Through strong key players who provide direction and motivation & 9 \\
\hline
\end{tabular}

Tab 3. FOG test (Lukesch, 2007:19) with the frequency of the LAGs' answers to the first 5 questions.

While in the case of the last two questions (see Annex 1 and Table 4.) the answers belonging to the highest type of governance were the most regular answers. 


\begin{tabular}{|c|c|c|}
\hline $\begin{array}{l}\text { 7. How is } \\
\text { communication } \\
\text { and networking } \\
\text { organised? }\end{array}$ & $\begin{array}{l}\text { 8. Local actors share coordination functions for local development in varying } \\
\text { constellations }\end{array}$ & 11 \\
\hline $\begin{array}{l}\text { 8. How is } \\
\text { selfdetermination }\end{array}$ & $\begin{array}{l}\text { 7. Local development strategies and measures are negotiated by the concerned } \\
\text { actors }\end{array}$ & 9 \\
\hline $\begin{array}{l}\text { responsibility } \\
\text { dealt with? }\end{array}$ & $\begin{array}{l}\text { 8. The local level self-organises local development in cooperation with other levels } \\
\text { of decision-making }\end{array}$ & 3 \\
\hline
\end{tabular}

Tab 4. FOG test (Lukesch, 2007:19) with the frequency of the LAGs' answers to the last 2 questions.

In our experience the group of "concerned actors" and "varying constellations" is narrow, related to the possible actors in a village.

\section{Operations}

Table 5 shows the actions (initiatives) undertaken (or supported) by the LAGs classified through the three categories of the applied model, such as animation, structuring and consolidating (Lukesch, 2007:23). Results show, that presence of animation actions between the three type of actions give the highest percentage, however, according to Lukesh (ibid.) to the level of governance (3.7) that the examined LAGs represent, animation actions should have an even higher role.

\begin{tabular}{|l|r|r|r|}
\hline & Animation actions & Structuring actions & Consolidating actions \\
\hline LAG1 & 39.0 & 30.0 & 31.0 \\
\hline LAG2 & 38.0 & 33.5 & 28.5 \\
\hline LAG3 & 35.7 & 25.0 & 39.3 \\
\hline LAG4 & 35.8 & 31.3 & 32.8 \\
\hline \hline Average & $\mathbf{3 7 . 1}$ & $\mathbf{3 0 . 0}$ & $\mathbf{3 3 . 0}$ \\
\hline
\end{tabular}

Tab 5. Results of the frame examining the presence of different type of operations. Source: own calculation.

The data gained from the applied model tell us that the level of the LAGs' governance in the examined regions is low. At this stage inside action the need for animation type initiatives is high. While animation type initiatives have the highest presence in most of the examined regions, their presence does not match Lukesch's model. They play lower, while consolidation actions higher role. Although structuring actions are present at the Hungarian LAGs, they are mainly based on selecting from initiatives based on traditional values. Thus, innovative ideas are often missing. Giving not enough space for animation actions, results consolidation actions bring could be lower, loosing actors and possible solutions in the region. It is better to arrive to consolidation phase when there was enough space for common learning, dialogues where possibilities for the future are more diverse.

Lukesch ${ }^{5}$ states, that "animating actions are undertaken in order to create variety. They are less indicated if there is already a multitude of little initiatives competing for scarce resources. Structuring forces mean selection from the ideas. Finally, consolidating actions mean stabilisation. The containers created to pursue new ideas (organisations, firms, value chains etc.) are now mature to create value added over time. This requires investments into effectiveness and efficiency, quality and knowledge management, often hand in hand with boosting networking skills on a wider, maybe global scale."

\footnotetext{
${ }^{5}$ Letter from the author of the LAG Handbook to the author of this paper, regarding the application of the method he created in his work on governance and operations.
} 


\section{Discussion}

\section{Role of animation actions in Hungary}

The literature on rural development suggests that social animation is an indispensible part of addressing rural problems and creating long lasting positive structural changes. This suggests that it should be in the heart of the implementation of the LEADER programme.

Varga (2009) in her work, investigating LAGs in the Southern Transdanubian Region of Hungary, also positioned the actors somewhere in the middle of Lukesch's model. For examining the applied operations she looked at examples of them by collecting concrete activities: projects in the regions. In her study structuring actions had the highest importance between the applied projects. We presume that if the frame used in this study had examined the operations through concrete applied projects, the results would have shown a higher percentage of structuring actions in the examined North Great Plain region as well and lower in the case of animation actions.

Both studies call attention to a future need for the ratio of animation actions to be increased, since a significant proportion of the rural non-profit organisations and rural population still need to be mobilized. Varga (2009) demonstrates that non-profit organisations accounted for the highest share in implementing animation projects.

LAGs of the NATURAMA (2010) network in their proposal (for a better application of the third and fourth axis of the Hungarian National Rural Development Plan) also call the attention that mobilisation of local inhabitants, development and planning, which should be their most important task, comprises only 5-10 \% of their work. LAGs work linked to bureaucracy and administration in the changing environment takes the time of a lot of active players of rural areas, who, even offering their free time, would be ready to mobilise inhabitants to act in the interest of the region they live in. This problem of rapidly changing, unclear regulation was raised in the study of Kovách and Kristóf (2009, see introduction) as well. A current example for administration task over mobilisation is that LAGs were asked to make a review of their local development strategies in May 2010 (waiting months for acceptance) and now at the beginning of 2011 they have to review it again.

The proposal of NATURAMA underlines that trust and moral control should be important elements in the success of the programme. Although in the case of co-operatives (who are important actors of rural areas) Szabó (2010:16) also highlight the role of trust. He emphasizes that trust is usually considered as one of the main benefits which can help co-operative members to realise their economic and non-economic aims. He concludes that more empirical analyses are needed on the subject of trust-generating processes as well as on the development of trust. Animation actions could give place for such processes to increase trust between the actors of rural regions, even in the case of co-operatives.

Buday-Sántha (2009:937) characterises rural regions in Hungary as places where unemployment is high, the level of education is low, infrastructure and public services are insufficient and no positive vision for the future exists. It is not surprising therefore that the most common answer given to the first question of the FOG test - what is the essential theme for people in the area- was to fight for survival. Fehér (2005:65) presumes, that local communities and human relations are very important but currently very weak resources of Hungarian rural economies. He thinks that their mobilisation, strengthening is a key element in the success of the answers given to poverty and exclusion.

In our opinion animation actions could speed up the transition and shorten the period of change in the case of social embeddedness, even if this is not an immediately visible transformation (not forgetting that the period which is shortened is 50 years. For example if we shorten it by 10 years it is difficult to notice). On the other hand, when people "fight for survival", technical investments seems to be a better and more visible answer. The problem is that without social change the chance for a sustainable future is less. So, animation is essential to the development philosophy of LEADER, even if it is not supported sufficiently by the programme. 


\section{Case studies on animation action in Hungary}

In this section we look at how animation can work. We examine 2 case studies that demonstrate this. The first looks at an innovative application of film-making with communities (participatory video) to demonstrate the sort of approach that can be used. The second focuses on the role of mediating actors (animateurs) to facilitate social animation.

\section{Social animation and evaluation through participatory video in rural development - application in Hungary}

Participatory video has been defined as a "...social and community-based tool or individual and group development" (Shaw \& Robertson, 1997), where non-experts are facilitated in using technology to make sense of their experiences. As with Freire's (1972) conscientiousness, participants are presented with the opportunity to become the subjects and not just the objects of a learning process. It is therefore distinct from related applications of video to issues of social and environmental justice, such as Harding's (2001) video activism. As a community development practice it has a long history, but as a field of academic study there are less sources to refer to. The concept of participatory video essentially dates back to the advent of accessible video technologies in the late 1960s and early 1970s.

It is difficult to pin PV down with a single definition, possibly because its history is not unitary. Yet although it has been said that there is no common understanding of PV (Huber, 1998, Pettit et al, 2009) there is an emerging awareness of the centrality of participatory values and processes at its core. The flexibility, innovation, openness and its amusing nature makes PV an excellent tool for social animation, community building and, at the end of the day, empowerment and self-presentation. To test PV as an actual rural (community) development tool, a pilot project was applied in Hungary, under LEADER+ (Nemes et al. 2007)

\section{The local context}

The Famulus Egyesület association hosted a pilot PV project in the Sümeg micro-region of midwestern Hungary, during the course of one week in July 2006. Famulus was then a recently established association (a year old at the time of the project) created by young craftsman of the area, aiming to emerge from their workshops, and gain influence in local affairs. The association gained momentum by winning the right to run the development agency of the local LEADER Action Group (LAG) which was also being established at the time. With this, LEADER became the principal arena for their activities. Famulus gained resources to run an office (with 2.5 people) publicity space and lots of contacts and responsibilities concerning the design and the implementation of a local rural development programme in a micro-region of 22 villages with 21,000 inhabitants, which was an important task. The people, working in this local development agency, became members of the inner PV project group. Although Famulus was a young organisation, it was successful and reasonably well known. This was due to the enthusiasm and capacities of their members and above all of their leader (the director), a talented young woman with many contacts and several years of experience in local and regional development work. Nevertheless, the organisation, as well as its members and employees, was still very much in the phase of finding its identity and way around within the local context.

\section{The project}

In mid June, a first, one day visit to Sümeg was carried out. The members of Famulus received a detailed description of the PV process, played around with the camera a little bit and a long sociological interview with the Famulus LEADERs to learn about the local context was also conducted. This extended introduction was perceived very well, members of the association got enthusiastic and started to buy in, gaining ownership of the project. They were given a written statement of what the project could offer, what was needed from them, and what approximate schedule the 6 days project would have. Everything was done to emphasise the participatory nature of the project from the very beginning. Nevertheless, as it turned out later, we were not quite able to get the message through. 
The one week project (from Monday to Saturday) was facilitated by an international team of experts, including a range of nationalities and expertise. After an introductory workshop, the first activity was a scriptwriting workshop. Around 15 core members of the association brought together their common knowledge of their activities, motivations, and past and future objectives. This process drove a very deep discussion because to be able to present themselves in a film, the group had to bring a lot of tacit knowledge to a conscious level. Although this was a long process, it engaged people in the process and kept their attention. The script itself was just one result from this process, and in retrospect there were other important things going on too. Discussing how to tell their story together seemed to liberate a lot of positive energy and have a strong empowering effect.

The resulting film was shot by members of the group over the following days; primarily interviews with group members and other local stakeholders, cut together with some reflection and stories and images of Sümeg. Thus making the film meant the members of the group talked with people they had seldom met with before in order to investigate how the association was helping them or not. For those taking part in the interviews, it was an opportunity to talk about all that things that are behind everyday work: values, vision, and desires. This provided them with much useful information as well as raising their profile locally. Also, many members of the local community were drawn into the process, gained skills, information and contacts.

Subsequent research tracking the effects (Nemes and High, 2009) has shown the most important outcomes were a very strong development of the local community, an experience of empowerment and a strong example of successful co-operative work within the group's experience. Indeed the association became one of the best known LEADER groups in Hungary. This is not to say that this all is the result or the consequence of the PV project, but thanks to some fortunate circumstances and timing, the project has seemed to reinforce their development. Following their participation, self-reflection, group activities and even the use of PV as a facilitation tool became part of their institutional culture. This example demonstrates a number of important features often observed in reports on participatory video. For example, though making a film that was good enough to show others was a common goal, the social process of making the film and the benefits that came from it in terms of learning and improving relationships was experienced as far more important - process over product (Ferreira, 2006; White 2003). Not all the engagement was positive however, and in retrospect there were probably individuals who would have liked to contribute more than they were able, because of their social position in relation to the group, lack of desire to engage in a team activity or the particular set of skills they brought (or not) to the process. Yet for the majority of participants, the enthusiasm and engagement is quite typical too (High, 2010; White, 2003), and this was enhanced by the short-term, festive nature of the project.

\section{Role of Universities}

The EU project ALICERA (Schockemöhle et al., 2010) tested whether Rural Action Learning $(R A L)$ is able to effectively promote regional identity and had the result that RAL successfully enable the promotion of participatory competence and regional identity in those who take part at all age levels. Younger participants tend to show stronger parameter changes than adults. Also the close interaction between regional identity forming and acquisition of participatory competence was empirically confirmed. Regional action-oriented learning promotes the identity formation and the acquisition of participatory competence (what is important, because that is a still lacking attribute in Hungary).

In our experience Universities could play a role in increasing the animation operations (RAL, PV) in rural areas. Teachers at Universities could play a central role as link between LAGs through students and building relations with the national and European RD Networks.

We agree with Rabbinge and Slingerland (2009:60) that the relative independence of students in deciding their research theme, choosing their research location is very important as success of their work is determined by how they like the job they have to carry out. If it is a work on their own interest they do not mind working more for getting better results. An empirical research 
selected by a student linked to rural development can create animation actions. Some examples from the students of the authors:

- organisation of a local forum, where participatory video was presented and there were a place for final discussion. The student faced the problem of inactive participation, without comments, questions regarding the future possibilities. After the forum, she got a feed back "we are too old to this, to form opinion on the future"

- carrying out questionnaires linked to the knowledge about the LEADER programme. Even by asking questions linked to the LEADER in their region people could learn a bit about the programme. It turned out along this work, that their information is very low and they do not participate in local forums.

- publishing the results in local newspapers. Examining the role and culture of a local minority finally one student get the possibility to publish her results in a local newspaper. Communication from local students in the direction of local inhabitants has a better acceptance than from politicians. This also increases the regional identity the attachment to the place of a young local inhabitant, with which the possibility for her not leaving the territory increase.

On the bases of these results we also had the experience as Rabbinge and Slingerland (2009: 60 ) that the degree of involvement of potential end users, also provides ingredients for students to develop into critical, independent, reflexive research that have a contribution to make to both science and society. Bodorkós and Pataki (2009) in their work on applying participatory action research to establish democratic communicative spaces for sustainable rural development also emphasize the importance of the usage of knowledge generated through research for something useful to local communities.

Drawing up a possible space to improve the role of Universities in animation actions (Figure 2) we emphasize the role of European Network for Rural Development (EN RD) and also National Networks for Rural Development (NN RD). They could serve as an information forum. Methods developed along research programmes or researchers (as in our case the work by Lukesch) could be channelled in these networks from where faculties or departments of Universities interested in rural development and their students could draw linked to their interest. Students, through participatory action research, PVs, rural action learning could create animation actions in given areas, making connection with LAGs as well and increase local identity. Their work could be traced back to NN RDs and the EN RD, which could serve also as a monitoring of rural development, LEADER all over Europe. As students speak better foreign languages as rural inhabitants, those carrying out these researches through their work - even in a case of comparison LAGs - could also help in connecting LAGs between member states.

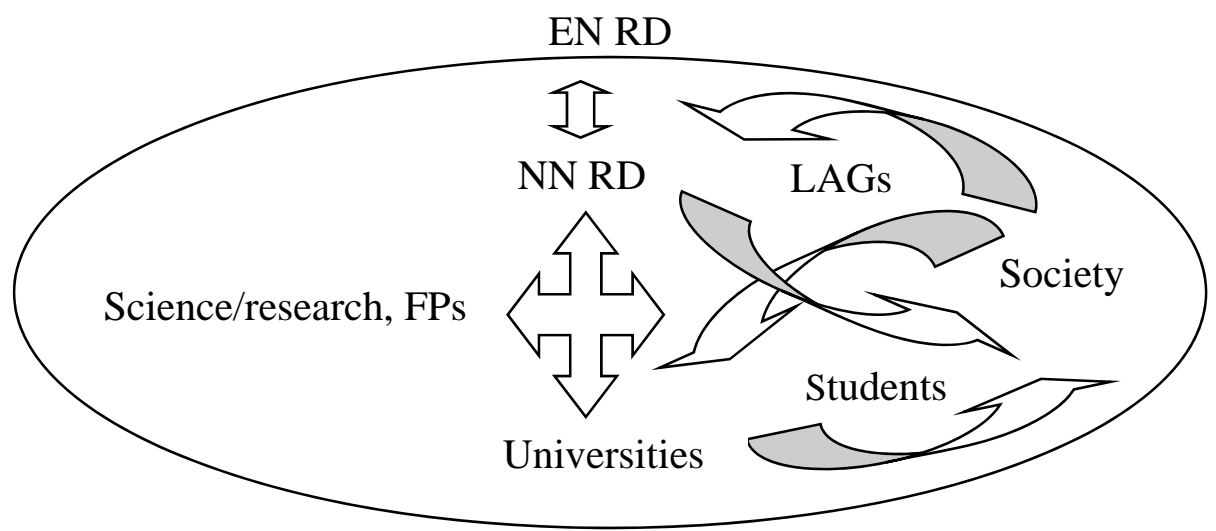

Fig 2. Possible actors of animation actions to develop rural areas. Source: own illustration.

There are good examples already, noticing the capacity of Universities, such as the University and lagging regions program, or even the existence of NATURAMA network (linking LEADER groups of environmentally protected areas) is a result of an action research programme. 
This institution could be a place for foreign animation actions as well, even through PVs, which could be shared between foreign students through internet.

Finally, an important aspect of these operations carried out by students (above increasing the capacity involved in animation actions) is, that the cost behind them is very low.

\section{Conclusion}

Can we shortcut 20-50 years of cultural change in rural development? Are we heading in the right direction at all? Why have non-LEADER actors involved in animation in LEADER, when the heart of the LEADER approach is about activating and building on local governance capacity (i.e. wider than local governance - drawing on the strengths of the local heuristic system). This is, if you think about it, the main point of neo-endogenous development - how to draw on the best of what outsiders and insiders have to offer.

In our view, what the case studies show is that it's perfectly reasonable to have PV agents or a university involved in animation actions in a context where animation capacity is lacking. Animation is a soft skill, learned through socialisation and innovation. Where micro-level governance is very bureaucratic, there isn't time and space for either. So it may be necessary to draw on other contexts where there is a better established tradition of social animation, or where there is time and space to take risks and innovate in order to build up the social context which lies behind animating capacity.

We cannot jump 50 years of evolution of rural society and economy by simply spreading public money, supporting development projects, building institutions. However, as an examination of the LEADER Programme shows, through strategically planned and implemented social animation, based on subsidiarity, bottom-up participation, etc. the process can (and should) be significantly accelerated and reinforced.

Our research has shown that in Hungary the importance of social animation was not sufficiently recognised by the management authority and/or by some of the LAGs. Thus, the development and professionalization of formal institutions has diverged from the organic development of local development capacity, skills and social networks. All this is now clearly creating great difficulties and dysfunction in the system of Hungarian rural development. If social animation is not taken more seriously, social networks, local participation, and the culture of co-operation and making decisions are not improved through a clear, strategic approach, then we cannot hope to head towards an improved system of rural development in Hungary.

A significant change in the approach of the Ministry and other central institutions is difficult to imagine in Hungary. Centralised management and decision making, and the weak application of multi-level governance is likely to persist and use up much of the available resources. However, if even small amounts of money for networking, co-operation, and social learning in LEADER are made available, then this can release external capacity and resources (research budgets, other EU programmes, volunteer efforts, etc.). Thus, social animation and social learning can occur in a much more significant manner, and rural development can achieve better results.

References

[1] Bodorkós, B. \& Pataki Gy. (2009). Local communities empowered to plan? Action Research 7(3), 313-334. Doi: 10.1177/1476750309336720.

[2] Buday-Sántha, A. (2009). A magyar agrár- és vidékfejlesztés ellentmondásai. Magyar Tudomány 2009/8, 937-945.

[3] Fehér, A. (2005): A vidékgazdaság és a mezőgazdaság. Budapest: Agroinform Kiadó.

[4] Ferreira, G. (2006). Participatory video for policy development. University of Guelph.

[5] Freire, P. (1972). Pedagogy of the Oppressed. Harmondsworth: Penguin Books.

[6] Harding, T. (2001). The video activist handbook. London: Pluto Press. 
[7] High, C. (2010). Social Learning in the Context of Adaptation to Climate Change. Paper presented at the International Workshop on The Social Dimension of Adaptation to Climate Change, Venice.

[8] Huber, B. (1998). Communicative aspects of participatory video projects: An exploratory study. Unpublished master thesis. Uppsala: Swedish Agricultural University.

[9] Katona-Kovács, J. (2010). Alignment of rural and regional programmes and funding. Workshop Slide presented at the RuralJobs FP7 research closing conference http://www.region-limousin.fr/ruraljobs/?cat=16.

[10] Kovách, I. \& Kristóf, L. (2009). The Role of Intermediate Actors in Transmitting Rural Goods and Services in Rural Areas Under Urban Pressure. Journal of Environmental Policy and Planning 11(1), 45-60. DOI: 10.1080/15239080902775025.

[11] Kovács, G. (2004). Rural policies and LEADER+ in Denmark and Hungary. Working paper. Esbjerg: The Danish Centre for Rural Research and Development.

[12] Loorbach, D. \& Rotmans, J. (2006) Managing transitions for sustainable development. In Poppe, K.J. et al., eds. Transitions towards sustainable agriculture and food chains in peri-urban areas. Wageningen Academic Publishers.

[13] Lukesch, R. (2007): The LAG handbook: A guide through the stunning world of local action groups. http://ec.europa.eu/agriculture/rur/LEADERplus/pdf/library/methodology /lukesch_handbook.pdf. Accessed September 2009.

[14] Naturama (2010): A NATURAMA Szövetség Akciócsoportjainak javaslatai az UMVP III. IV. tengelye intézkedéseinek hatékonyabb megvalósitása érdekében.

http://www.naturama.hu/ptPortal/index.php?mod=news\&action=showNews\&newsid=1192 7\&lang=hu.

[15] Nemes, G., \& High, C. (2009). Social learning in the project state. Paper presented at the XXIII European Society For Rural Sociology Congress "Re-inventing the rural: between the social and the natural", Vaasa, Finland.

[16] Nemes, G., High, C., Shafer, N., \& Goldsmith, R. (2007). Using participatory video to evaluate community development. Paper presented at the XXII European Congress of Rural Sociology, Wageningen, Netherlands.

[17] Nemes, G., Chris, H. \& Huzair, F. (2006): Reflexive agency and multi-level governance: Mediating integrated rural development in South Transdanubia. In Cheshire, L. Higgins \& V. Lawrence, G. (eds.), International Perspectives on Rural Governance: New Power Relations in Rural Economies and Societies. London: Routledge.

[18] Odor K., Karcagi-Kováts, A. \& Kuti, I. (2009):. Rural areas under the pressure of population decrease. "AGRARIAN PERSPECTIVE XVIII. - Strategies for the Future" Collection of Papers of International Scientific Conference, Prague, Czech University of Life Sciences, September 2009.

[19] OECD (2007): OECD Rural Policy Review - Case Finland. Background report for OECD. Helsinki, 2007. http://www.helsinki.fi/ruralia/research/inkling/attachment/OECD_ background_report_FINAL_200507.pdf. Accessed December 2010

[20] Pettit, J., Salazar, J. F., \& Dagron, A. G. (2009). Citizens' media and communication. Development in Practice, 19(4/5), 443-452.

[21] Ploeg, J. D. van der, Oostindie, H., Broekhuizen, R. van, Brunori, G., Sonnino, R., Knickel, K. \& Tisenkopfs, T. (2008). Towards a new theoretical framework for understanding regional rural development. http://www.etuderd.eu/dynamic/media/1/files/ D_2.2_ETUDE_WP2_Synthesis_Report.pdf. 25 pp. Accessed January 2008.

[22] Rabbinge, R. \& Slingerland, M. (2009). Change in knowledge infrastructure: the third generation university. In Poppe K.J. et al, eds., Transitions towards sustainable agriculture and food chains in peri-urban areas. Wageningen Academic Publishers. 
[23] Salverda, I., Slangen, L., Kruit, J., Weijschedé, T. \& Mulder, J. (2009). History is alluring: self-organisation and the significance of history in the search for a new local sense of collectivity. In Poppe K.J. et al, eds., Transitions towards sustainable agriculture and food chains in peri-urban areas. Wageningen Academic Publishers.

[24] Shaw, J., \& Robertson, C. (1997). Participatory video: A practical guide to using video creatively in group development work. London: Routledge.

[25] Schockemöhle, J., Kalmárné-Hollósi, E. \& Cser, J. (2010). Rural Action Learning promoting competences and strengthening participation. In Fieldsend, A., ed., Linking competitiveness with equity and sustainability: new ideas for the socio-economic development of rural areas (pp 7-23). Warsaw: European Rural Development Network.

[26] Szabó, G. (2010). The Importance and Role of Trust in Agricultural Marketing CoOperatives. MTA - AKI, Budapest: Studies in Agricultural Economics, No. 112, pp 5-22.

[27] Terluin, I. J. \& Post, J. H. (1999). Employment in leading and lagging rural regions of the EU: Summary report of the RUREMPLO project. http://www.lei.dlo.nl/ publicaties/PDF/1999/4_xxx/4_99_10.pdf. 53 pp. Accessed January 2008.

[28] Varga, E. (2009). Non-profit organisations in Hungarian rural development - a LEADER+ example in the Southern Transdanubian Region. European Countryside 1(2), 93-104. Doi: 10.2478/v10091/009-0008-2.

[29] Weber, G. (2010). Shrinking process in rural areas. Presentation at the EURORURAL '10 European Countryside under Globalisation Conference, Brno 2010.

[30] White, S., Ed. (2003). Participatory video: Images that transform and empower. London: Sage.

[31] Woodhill, J. (2008): How institutions evolve - Shaping behaviour. The Broker Issue 10, pp 4-8; http://www.thebrokeronline.eu/en/Magazine/articles/Shaping-behaviour. 